\title{
Parateksty gier cyfrowych - odbiór gry a paratekstualne funkcje i procesy
}

\author{
Michał Żmuda
}




\section{Propozycje}

\section{Parateksty gier cyfrowych - odbiór gry a paratekstualne funkcje i procesy}

MichałŻmuda

TEKSTY DRUGIE 2017, NR 3, S. 363-380

DOI: $10.18318 /$ td.2017.3.22

W ydana w 2016 roku gra polskiego studia Bloober Team, Layers of Fear, utrzymana jest w konwencji horroru. Produkcja umożliwia graczowi wejście w rolę ogarniętego szaleństwem malarza. Podczas przemierzania wiktoriańskiego domu główny bohater stopniowo odkrywa (przed samym sobą i graczem) sekrety własnej przeszłości. Gra ukazała się w dwóch wersjach: standardowej i kolekcjonerskiej (nazwanej „edycją konesera”). Wydanie specjalne zostało wzbogacone o książeczkę, która prezentuje prace graficzne wykonane na potrzeby gry. Znalazły się w niej materiały koncepcyjne, które posłużyły za punkt wyjścia do produkcji interaktywnego środowiska gry; a także prace plastyczne, szkice, dziecięce rysunki, wycinki z gazet, reprodukcje zdjęć, dokumenty medyczne i teksty literackie - elementy diegezy Layers of Fear. Książka przywołuje świat gry, odtwarza jej poetykę i atmosferę, ewokuje też tradycję malarską, która zainspirowała jej twórców.

Obecność materialnego artefaktu domaga się zapytania o jego status względem cyfrowej gry. Czy jest on
Michał Żmuda - mgr, doktorant na Uniwersytecie Rzeszowskim, interesuje się paratekstualnością i intertekstualnością gier, a także przenikaniem się mediów. Kontakt: michal. zmuda@onet.pl 
zaledwie estetycznym gadżetem, który nie odgrywa większej roli w odbiorze, czy może pełni funkcję istotnego dopełnienia, które współuczestniczy w procesach znaczeniowych? Czy jego ewentualny brak jest podczas rozgrywki odczuwalny?

Powyższe pytania można odnieść do licznych materiałów, które bywają załączone do wydań cyfrowych gier, np. książek, fikcyjnych gazet, instrukcji. Problem dotyczy metodologii badania artefaktów tego typu, ich wpływu na odbiór gry oraz ich statusu w szerszym dyskursie kulturowym. U sedna niniejszego artykułu leży przekonanie, że odpowiedzi na wskazane zagadnienia należy szukać w teorii paratekstualności, którą zaproponował francuski badacz Gérard Genette.

\section{W przedsionku}

Koncepcja paratekstu została po raz pierwszy zarysowana w książce z 1982 roku Palimpsestes. La Littérature au second degré (wydanej w Polsce pod tytułem Palimpsesty. Literatura drugiego stopnia). Przedmiotem pracy była transtekstualność, czyli „transcendencja tekstualna tekstu” - zbiór zjawisk wiążących dany tekst z innymi tekstami'. Genette wyróżnił pięć typów relacji transtekstualnych, w tym interesującą nas paratekstualność. Badacz szkicowo nakreślił rodzaj komunikatów literackich zaliczanych przez niego do tej kategorii. Wśród nich znalazły się m.in. tytuły, przedmowy, posłowia, wstępy, noty, epigrafy i ilustracje $e^{2}$. Pojęcie paratekstu doczekało się dokładnego omówienia dopiero pięć lat później w pracy Seuils (do dziś nieprzetłumaczonej na język polski³).

Genette opisuje paratekst za pomocą metafory progu (tytułowe seuils), porównuje go do westybuli. Jak zauważa, paratekst tworzy przestrzeń nie do końca zdefiniowaną, zawieszoną między tym, co wewnątrz (czyli tekstem, do którego dany paratekst się odnosi), a tym, co na zewnątrz (czyli dyskursem o tymże tekście). Jest to przestrzeń, która umożliwia „wkroczenie” w tekst i jego interpretację. Paratekstami są zatem komunikaty, które „towarzyszą” danemu tekstowi, które go otaczają i jednocześnie uzupełniają, czyniąc go

1 G. Genette Palimpsesty. Literatura drugiego stopnia, przeł. T. Stróżyński, A. Milecki, słowo/obraz terytoria, Gdańsk 2014.

2 Tamże, s. 9.

3 Podstawą niniejszego artykułu jest angielskie tłumaczenie tej pracy: G. Genette Paratexts: Thresholds of interpretation, trans. J.E. Lewin, Cambridge University Press, Cambridge-New York 2001 
gotowym na odbiór przez czytelnika. Nadrzędnym celem paratekstów jest wpływanie na recepcję tekstu. Są one przejawem próby zawładnięcia nad jego odbiorem, tak by był on zgodny z intencjami podmiotów, które dany tekst wyprodukowały (np. autora, wydawcy, tłumacza). Stąd też stwierdzenie Genette'a, że parateksty czynią tekst „obecnym” w kulturze, a co za tym idzie, wniosek, że tekst nie istnieje bez paratekstów ${ }^{4}$.

Idea paratekstu jest głęboko zanurzona w literaturoznawstwie. Genette sugeruje uniwersalność tego zjawiska, stwierdzając, że parateksty to heterogeniczna grupa różnorodnych praktyk i dyskursów ${ }^{5}$, oraz zwraca uwagę na fakt, że mogą one przybierać formę nie tylko werbalną, ale także ikoniczną i materialną. Naukowiec szybko jednak porzuca ten wątek i swoje analizy poświęca wyłącznie przypadkom okołoksiążkowym. Adaptacja teorii paratekstu do badania gier cyfrowych może więc wzbudzić wątpliwości. Jak pogodzić literacką metodologię z badaniem artefaktów, w których komunikacja werbalna może stanowić zaledwie jedną z wielu różnych poetyk reprezentacji i które pod względem właściwości medialnych znacznie odbiegają od formy kodeksu?

Na gruncie badań anglosaskich wstępną próbę otwarcia metody paratekstualnej na badanie praktyk medialnych podjął Georg Stanitzek. W artykule Texts and Paratexts in Media sugeruje on odejście od przywiązania do rozumienia tekstu (i literatury w ogóle) jako teorii równoznacznej z formą książki ${ }^{6}$. Stanitzek proponuje wzbogacić paratekstualność o kontekst medioznawczy, a same parateksty traktować jako elementy organizujące komunikację. Nie podaje jednak konkretnego rozwiązania. W jego artykule brakuje bowiem jednoznacznego odniesienia paratekstualności do sytuacji współczesnych praktyk medialnych. Problem ten został jednak rozwiązany przez polskiego medioznawcę Andrzeja Gwoździa, który w pracy Obok filmu, między mediami zmodyfikował definicję paratekstów, nazywając je wiązkami praktyk dyskursywnych, „dzięki którym bazowy tekst (audio)wizualny lub samo medium [...] włączone zostają do środowiska szerszego niż to, które zapewnia pa-

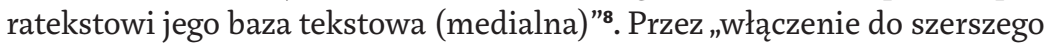

4

\section{Tamże, s. 3-4.}

Tamże, s. 2.

G. Stanitzek Text and Paratexts in Media, trans. E. Klein, "Critical Inquiry” 2005 No. 32 (1), s. 31-32.

Tamże, s. 35-36.

A. Gwóźdź Obok filmu, między mediami, w: Pogranicza audiowizualności, red. A. Gwóźdź, Universitas, Kraków 2010, s. 36. 
środowiska” Gwóźdź rozumie „przejście na styku kodowania zewnątrz- i wewnątrztekstowego", które otwiera pole interpretacyjnych negocjacji między nadawcami i odbiorcami ${ }^{9}$. Istota działania paratekstualności nie zmienia się więc, badacz rozszerza jedynie zakres tego pojęcia, argumentując, że w obecnej sytuacji kulturowej parateksty „rozbudowane zostały do form i pasm dalece wykraczających poza jakości literackie [...]"10.

Warto jeszcze wspomnieć, że metoda paratekstualna znalazła już zastosowanie w studiach nad grami. Badacze wykorzystali pomysł Genette’a m.in. do rozważań na temat pozadiegetycznych ram interpretacyjnych gier"1, tekstów będących metatekstualnymi komentarzami gier ${ }^{12}$ czy też fizycznych właściwości analogowych dodatków ${ }^{13}$. Jednym z głównych aspektów paratekstualności, który w dotychczasowych badaniach gier został zmarginalizowany, jest związek tego zjawiska z próbą autorskiej kontroli nad recepcją tekstu. W niniejszym artykule postaram się skoncentrować właśnie na tej kwestii. Pisząc o autorskiej kontroli, mam na myśli pewną idealną wizję odbioru, którą chcą graczowi narzucić różne podmioty zaangażowane w produkcję gry: od producentów, przez zespoły programistów, grafików i scenarzystów, a na specjalistach od marketingu kończąc. Powyższe założenie jest zgodne z koncepcją Genette'a, gdyż on sam zwracał uwagę na skomplikowany proces wydawniczy, który stoi za powstawaniem książkowych paratekstów.

Moja analiza będzie więc dotyczyć różnych tekstów, których celem jest wpływanie na odbiór gry. Podążając za założeniami teoretycznymi Gwoździa, rozszerzę zakres badanego materiału na obiekty, które spełniają kryterium bycia „wiązkami praktyk dyskursywnych". W tym ujęciu paratekstualność to już nie tylko takie komunikaty jak tytuły czy stopki wydawnicze, ale także

9 Tamże.

10 Tamże, s. 36-37.

11 A. Rockenber Video Game Framings, w: Examining Paratextual Theory and its Application in Digital Culture, ed. by N. Desrochers, D. Apollon, Information Science Reference, Hershey 2014, S. $252-286$.

M. Consalvo Cheating. Gaining Advantage in Videogames, The MIT Press, Cambridge 2009; M. Carter Emitext and Paratexts: Propaganda in EVE Online, "Games \& Culture" 2015 No. 10 (4), s. 311-342; S. Mukherjee Video Games and Storytelling. Reading Games and Playing Books, Palgrave Macmillian, Houndmills-Basingstoke-Hampshire 2015.

13 C.A. Kocurek The treachery of pixels: Reconsidering feelies in an era of digital play " ")ournal of Gaming \& Virtual Worlds" 2013 No. 5 (3), s. 295-306. 
inne media. Dzięki temu założeniu materiał badawczy może zawierać opakowania gier, instrukcje, broszury, nakładki na kontrolery.

Genette postuluje, aby badać parateksty w ich wymiarach: przestrzennym, czasowym, materialnym, pragmatycznym i funkcyjnym ${ }^{14}$. Tak szeroki zakres wydaje się wykraczać poza możliwości ramowe artykułu, dlatego ograniczę się w nim do omówienia podstawowych funkcji, jakie pełnią parateksty gier (nie zapominając o istnieniu pozostałych aspektów, które na te funkcje wpływają). Wybór ten jest podyktowany przekonaniem, że pozwoli to zrozumieć kluczowe cele, jakie stoją za włączeniem paratekstów w proces recepcji. W dalszej części artykułu wyróżniam i analizuję trzy główne funkcje paratekstów gier: narracyjną, medialną i ekonomiczną. Przyjęty podział ukazuje, że parateksty rozszerzają narracje i światy kreowane przez gry, definiują medialność gier (konfrontując je z tekstami o odmiennych właściwościach), a także, że są uwikłane w materialne i rynkowe aspekty produkcji. Przejdźmy zatem do bardziej szczegółowego spojrzenia na każdą z tych funkcji.

\section{Funkcja narracyjna}

Pierwsza z wymienionych funkcji dotyczy zdolności paratekstów do pogłębiania warstwy narracyjnej gier. W tym wypadku parateksty mogą służyć rozwinięciu przedstawianej historii, zaprezentowaniu wątków i postaci niewystępujących w grze i/lub zapoznaniu użytkownika ze światem przedstawionym.

Narracyjne parateksty gier realizują cztery ogólne cele. Przede wszystkim mogą być fabularnymi suplementami historii przedstawionych w grze. Najmniej skomplikowaną formą takiego uzupełnienia są krótkie notki fabularne zamieszczane na opakowaniu gry bądź w instrukcji. Informacje tego typu przedstawiają zwykle zarys lub sytuację wyjściową fabuły. Dla przykładu, okładka polskiego wydania gry przygodowej Faust informuje gracza (lub potencjalnego klienta w sklepie): „Jako rozważny starzec Marcellus Faust, ostatni strażnik opuszczonego wesołego miasteczka, musisz pokonać barierę czasu, aby zbadać mroczną przeszłość parku rozrywki [...]"15. Przypadek gier Essex i Beyond Divinity pokazuje jednak, że fabularna suplementacja może również przybierać bardziej rozbudowane formy. Beyond Divinity była sprzedawana wraz z opowiadaniem Rhianny Pratchett Dziecię Chaosu.

\footnotetext{
14 G. Genette Paratexts: Thresholds of interpretation, s. 4.

15 Cryo Interactive Entertainment Faust, CD Projekt 1999.
} 
Opowiadanie dzieje się w świecie przedstawionym gry, nie jest jednak bezpośrednio związane z jej osią fabularną. Stanowi wobec tego poboczny element głównego produktu. Nieco inaczej wygląda sytuacja książki, która wyznacza ramę narracyjną Essex. Wyznacza ją w sensie dosłownym, gdyż wydana przez Synapse i Brøderbund Production tekstowa gra została zapakowana nie w standardowe pudełko, a we wspomnianą książkę. Prozatorski utwór wprowadza postacie występujące w grze i opowiada o przyczynach wydarzeń, w których gracz weźmie udział. Znajomość tekstu towarzyszącego grze ułatwia początkową orientację w jej fabule; wspomaga interpretację historii generowanej podczas rozgrywki.

Parateksty mogą również przekazywać encyklopedyczne fakty o świecie gry. Mamy wówczas do czynienia nie z rozszerzeniem opowieści, a z zachęcaniem użytkownika do pogłębienia wiedzy o rzeczywistości przedstawionej. Zabieg tego typu jest popularny zwłaszcza w grach, które kładą nacisk na eksplorację i poznawanie fantastycznej rzeczywistości lub są osadzone w świecie znanym z innych tekstów. Akcja wydanej również w Polsce gry Baldur's Gate toczy się w Zapomnianych Krainach, jednym ze światów stworzonych na potrzeby gry fabularnej Dungeons $\diamond$ Dragons. Prawie dwustustronicowa instrukcja gry oprócz informacji o jej obsłudze zawiera również Vola przewodnik po Wrotach Baldura. Ten informator, rzekomo napisany przez fikcyjną postać z Zapomnianych Krain, „pomaga lepiej poznać świat gry i zawiera informacje o zasadach, jakimi się on rządzi"16. Co ciekawe we wstępie do instrukcji autorzy przyznają, że wiele wiadomości zawartych w przewodniku ,jest mało istotnych i nie trzeba ich posiadać, by dobrze się bawić"17. Mimo wszystko zachęcają do jego przeczytania. Gracz znajdzie w nim bowiem opisy miejsc, frakcji i istot, z którymi będzie mógł podczas rozgrywki wejść w interakcję. Podobny zabieg zastosowano w Ultima VII. Do opakowania gry oprócz reklam i informacji technicznych dodano książeczkę o tytule Fellowship. Identycznie jak w przypadku Baldur's Gate jest to zmaterializowany obiekt ze świata gry. Lektura tej książki zapoznaje użytkownika z historią, obyczajami, geografią i prawami panującymi w Britanni - krainie, w której toczy się akcja Ultima VII.

Opisane parateksty ukazują, w jaki sposób twórcy gier usiłują wpłynąć na odbiór kreowanych światów. Załączone przewodniki ukierunkowują tok myślenia gracza, klasyfikują elementy danego świata oraz nadają im konkretną

16 Black Isle Studios, Bioware Corp. Baldur's Gate, Opowieści z Wybrzeża Mieczy, CD Projekt 1999, instrukcja, s. 4 .

17 Tamże. 
rangę (Vola Przewodnik wymienia np. jedynie najpotężniejsze organizacje i najważniejsze postacie opisywanych krain). Światotwórcze parateksty mają za zadanie zainicjować fenomen interpretacyjny, który Umberto Eco nazwał „wycieczkami inferencyjnymi”. Każda lektura to proces, w którym czytelnik dokonuje nieustannej ewaluacji stanów fabuły i przewiduje przyszły przebieg akcji. Odbywa się on dzięki „wyjściu poza tekst”, gdyż „stawiając swą hipotezę czytelnik musi odwołać się do scenariuszy powszechnych lub intertekstowych [...] by udać się na poszukiwanie możliwych rozwiązań w repertuarze tego, co zostało już powiedziane"18. Repertuar ten może stanowić wiedza powszechna (kompetencje encyklopedyczne) bądź też szeroko rozumiany kontekst intertekstualny. Skoro możemy mówić o encyklopedii powszechnej (w ogólnym rozumieniu pewnego zbioru informacji o naszej rzeczywistości), to nie będzie również błędem mówienie o encyklopediach światów fikcyjnych. Analogiczną prawidłowość zauważył Krzysztof M. Maj, który w artykule Światotwórstwo w perspektywie narratologicznej stwierdza, że teza Eco sprowadza się do „przypisania każdemu światu, zarówno aktualnemu, jak i możliwemu, encyklopedii zapewniającej niezbędne do jego poznawania i rozumienia pole odniesienia $[\ldots]^{\prime \prime \prime}$. Załączane do gier materiały kontekstualizują fikcyjne światy. Tworzą pole odniesienia, które jest tożsame $\mathrm{z}$ wyobrażeniem autorów o tym, czym ten świat być powinien. Ingerują w wyobrażenia gracza o konsekwencjach jego działań bądź też następujących po sobie stanach fabuły. Poznanie świata gry zostaje w takich przypadkach zapośredniczone przez tekst, który im towarzyszy.

Książki dołączone do Essex i Beyond Divinity, przewodniki po rzeczywistości Baldur's Gate i Ultima VII zwracają uwagę na kolejną właściwość narracyjnych paratekstów. Są one nie tylko suplementami samych fabuł i światów przedstawionych, wprowadzają również niewystępujące w danych grach formy narracji i opisów. Powieść dołączona do Essex realizuje przecież linearny model narracji, który jest odmienny od interaktywnego modelu gry. Przewodnik po Britanni istnieje wyłącznie poza cyfrowym tekstem gry i próżno go szukać w jej interfejsie lub w świecie przedstawionym. Multiplikację różnorodnych poetyk reprezentacji widać wyraźnie na przykładzie Zork: Nemesis. Autorzy wzbogacili wydanie gry o dziennik śledczy agenta L. Bivotara, wypełniony notatkami, biurokratycznymi pismami, reprodukcjami zdjęć i map.

U. Eco Lector in fabula, przeł. P. Salwa, PIW, Warszawa 1994, s. 172-173.

\footnotetext{
K.M. Maj Światotwórstwo w perspektywie narratologicznej, "Literatura popularna" 2014 t. 2, s. 66-67.
} 
Doświadczenie cyfrowej gry zostaje tym samym rozbudowane o dodatkowe formy. Jednocześnie, poza jedną drobną informacją, która się w tej broszurze znajduje (jest to kod wymagany do przejścia gry), nie zawiera ona szczegółów niezbędnych do prawidłowej rozgrywki.

Pamiętnik dołączony do Zork: Nemesis jest nade wszystko materializacją przedmiotu ze świata gry. Pierwsza strona książeczki zawiera adnotację od dyrektora Narodowych Archiwów Frobozz (to właśnie we Frobozz toczy się akcja gry), która potwierdza autentyczność dziennika. Mamy tu do czynienia z fikcyjnym tekstem, który „urealnia” fikcyjne notatki fikcyjnej postaci. Śledztwo przeprowadzone przez agenta L. Bivotara wiąże się oczywiście z wątkami fabularnymi gry. Paratekst służy więc pogłębieniu narracji i świata przedstawionego Zork: Nemesis. Poprzez pozorowaną przynależność do diegezy gry daje on odbiorcy możliwość fizycznej i sensorycznej interakcji z tym światem. Reprezentacja fikcyjnej rzeczywistości nie ogranicza się do audiowizualnych środków, z których korzysta cyfrowe medium gry. Dzięki materialnej obecności woluminu wybrany składnik tego świata przenika do rzeczywistości gracza, w następstwie czego iluzja istnienia krainy Frobozz zostaje wzmocniona.

Dochodzimy do kolejnej właściwości narracyjnych paratekstów. Mogą być one tekstami lub przedmiotami, które pretendują do bycia obiektami diegetycznymi. Mówiliśmy już o fikcyjnych przewodnikach po światach Baldur's Gate i Ultima VII. Omawiana strategia paratekstów legła również u podstaw dokumentu, który dołączono do opakowania StarTropics, gry wydanej na Nintendo Entertainment System. Jest nim list od wujka Steve'a (postać z diegezy gry) skierowany do głównego bohatera, Mike’a (czyli także do gracza, który steruje jego poczynaniami), zapraszający go do wizyty na tropikalnej wyspie, gdzie, jak wynika z treści listu, Steve prowadzi badania archeologiczne. List w prosty sposób przedstawia więc początkową sytuację fabularną gry (ta rozpoczyna się bowiem od wizyty na wyspie), ucieleśnia istotny przedmiot fabularny i diegetyczny (zaproszenie jest początkiem przygody głównego bohatera) i, co najważniejsze, stwarza iluzję fizycznej ciągłości między światem cyfrowej gry a materialnym przedmiotem, który z tego świata pochodzi. Mniej więcej w połowie gry Mike trafia na bezludną wyspę. Jedyną możliwością ratunku jest skorzystanie z łodzi podwodnej, która wymaga aktywacji przez użycie specjalnego kodu. Dosyć pokrętną drogą gracz dowiaduje się, że kod został ukryty w liście; kartkę należy zanurzyć w wodzie, a ukażą się na niej niezbędne cyfry. Użytkownik musi wejść z listem w fizyczną interakcję, co wytwarza obustronną relację między grą i jej paratekstem. Gra komentuje sposób obchodzenia się z przedmiotem, a ten dostarcza informacji, która 
musi zostać przez gracza przeniesiona z powrotem do programu. Jaką rolę odgrywa zatem kreowanie współzależności między diegezą gry i paratekstami?

Na to pytanie odpowiedział Veli-Matti Karhulahti. Pozostaje mi jedynie powtórzyć za nim, że parateksty jako materializacja obiektów ze świata gry mają za zadanie potęgować poczucie „immersji” u gracza. Fiński badacz jako pierwszy zwrócił uwagę na immersyjny wymiar materiałów dołączanych do gier. W jego artykule nie pojawia się bezpośrednie odniesienie do teorii paratekstu, analizuje on jednak obiekty, które wpisują się w przyjętą przeze mnie koncepcję paratekstów. Karhulahti zbadał tzw. feelies ${ }^{\mathbf{2 0}}$ (drukowane materiały zamieszczane w pudełkach) interaktywnych fikcji Deadline oraz Witness i doszedł do wniosku, że są to rekwizyty, które służą „wzmocnieniu immersji wyobraźniowej" użytkownika. Immersja jest w jego pracy rozumiana bardzo ogólnie, jako stan, w którym odbiorca zostaje „wchłonięty” przez historię i świat danej gry lub identyfikuje się z postacią z gry ${ }^{21}$. Parateksty narracyjne wzmacniają poczucie przynależności użytkownika do świata gry. Mogą też wzmagać efekt utożsamiania się gracza z kierowaną postacią.

Nie jest to jednak regułą. Paratekstualność może doprowadzić do odwrotnego rezultatu i wytrącić gracza z iluzji zanurzenia w diegezie, każąc mu „wyjść" poza obszar tekstu gry. Interakcja z fizycznymi obiektami i ich medialna odmienność od cyfrowego programu przypominają o akcie narracji, który zachodzi nie tylko „wewnątrz" gry, ale i na jej obrzeżach. W konsekwencji to, co intensyfikuje narracyjny i fabularny wymiar gry, równocześnie ujawnia konwencjonalność tych mechanizmów. Funkcji narracyjnej towarzyszą zatem funkcje medialna i ekonomiczna, które nie służą kreacji świata i opowiadaniu historii, lecz objaśniają technologiczne konteksty gier.

\section{Funkcja medialna}

Mówiąc o funkcji medialnej, podążamy tropem Gwoździa i rozpatrujemy parateksty jako praktyki dyskursywne, czyli już niekoniecznie konkretne teksty, ale przedstawicieli wybranych praktyk medialnych. Funkcja medialna spełnia się, gdy parateksty komentują zasady i konwencje rozgrywki, opisują medialne właściwości gry bądź też porównują ją z innymi (często starszymi)

20 Jest to marketingowy termin używany przez firmę Infocom.

V-M. Karhulahti Feelies: The Lost Art of Immersing the Narrative, w: Proceedings of DiGRA Nordic 2012 Conference. http://www.digra.org/digitallibrary/publications/feelies-the-lost-art-of-immersing-the-narrative/ (28.02.2015). 
mediami. Funkcja ta ma więc na celu zdefiniowanie medialności gry. Wyraża autorskie wyobrażenie na temat tego, czym dana gra jest i jak należy intepretować jej cechy - zarówno pod względem kulturowym, jak i technologicznym. Dodatkowo służy temu, aby gracz odpowiednio (w mniemaniu autorów) użytkował grę i był świadomy posiadanego przez nią spektrum technicznych, reprezentacyjnych i ludycznych możliwości.

Paratekstami, które najwyraźniej realizują omawianą funkcję, są wszelkiego rodzaju instrukcje. Wprowadzają one komentarz na temat gry w celu ułatwienia użytkownikowi rozgrywki. Broszura załączona do gry Black Dahlia rzeczowo wyjaśnia, że „w każdym miejscu, w którym pojawi się wirująca strzałka, gracz może w jakiś sposób wpłynąć na otoczenie. Można wykonać jedną z kilku czynności. Na przykład, kursor akcji może oznaczać możliwość przybliżenia przedmiotu lub układanki. Może również pokazywać, że gracz jest w stanie manipulować jakimś obiektem lub też może wskazywać, że dostępne są opcje rozmowy z innymi postaciami w danym pomieszczeniu"22. Tekst omawia podstawowe interakcje możliwe w programie gry. Obiektywny opis kończy się jednak wytycznymi co do pożądanego zachowania gracza: „Zawsze pamiętaj przy oglądaniu przedmiotów, że kursor ten pełni różne funkcje, więc spróbuj wykonać na danym obiekcie tyle czynności, ile tylko można"23. Jest to już nie objaśnienie, ale zalecenie, jak należy grać. Instrukcja do Black Dahlia zawiera zresztą krótki poradnik, który krok po kroku prowadzi odbiorcę przez początek gry i doradza w kwestii czynności przydatnych na późniejszych etapach. Podobny zabieg odnajdziemy w polskiej instrukcji do Grand Theft Auto III, która w dwóch zdaniach informuje gracza, że kradzież samochodów jest istotnym elementem mechanizmów tej gry: „Ulicami Liberty City jeździ mnóstwo samochodów różnych marek i wiele innych pojazdów, które tylko czekają, aż nimi zawładniesz. Aby porwać jakiś samochód, zbliż się do niego i naciśnij Return/Enter; Joypad 4; Klawisz F”24. Parateksty mogą zatem narzucać określoną interpretację systemów gry, wartościować możliwe interakcje i sugerować konkretne style rozgrywki. Wszystko po to, aby doświadczenie gry było jak najbliższe intencji twórców.

Objaśnienia i wytyczne, jak obsługiwać grę, wiążą się w szczególności z ustalaniem jej medialnych atrybutów. Unaoczniają działanie medium i,

22 Take Two Interactive Black Dahlia, Lem 1998, instrukcja, s. 7.

23 Tamże.

24 Rockstar Games Grand Theft Auto III, Play-It 2002, instrukcja, s. 6. 
aby przywołać metaforykę Genette'a, wprowadzają je do kulturowego dyskursu. Już sam opis instalacji gry, tego, jak należy się z nią obchodzić lub jak w nią grać, określa jej medialne cechy. Nierzadko twórcy wprost artykułują zakładane przez nich wyobrażenia o statusie medialnym gry. Dzieje się tak we wstępie do instrukcji pierwszej części Wiedźmina, gdzie znajduje się esencjonalny opis wyznaczników tej polskiej produkcji: „Wiedźmin to powrót do tradycyjnej, wielowątkowej gry RPG. To próba nowoczesnego podejścia do gatunku klasycznego RPG [...] - opartego na fabule, dynamicznego, pełnego niespodziewanych zwrotów akcji, z oszałamiającymi wizualnie scenami walki, osadzonego w świecie, który pulsuje życiem. Masz do dyspozycji widok izometryczny $[\ldots]$, a także kamerę «zza pleców» [...]. Co więcej [...] gracz musi znaleźć wyjście z sytuacji niejednoznacznych moralnie, podejmować dobrze przemyślane, dojrzałe decyzje, które mają ogromny wpływ na dalszy rozwój historii" ${ }^{25}$. Zwraca tu uwagę porównanie z konwencją RPG, odwołanie do filmowych aspektów, podkreślenie toczącej się w grze symulacji rzeczywistości („świat, który pulsuje życiem”) i możliwości wpływania na fabułę. Przytoczony opis osadza Wiedźmina w szerszym kontekście mediowym i wyraźnie przedstawia cechy, które według autorów definiują ich grę; cechy nie przypadkiem sytuujące ją wobec innych mediów. Jak zauważyli Jay David Bolter i Richard Grusin, media we współczesnej kulturze nie działają w izolacji, są częścią systemu wzajemnych odniesień i zależności. Reprezentacyjny potencjał medium ujawnia się dopiero wtedy, gdy zostanie skonfrontowany z innymi mediami. To właśnie konfrontacja umożliwia rozpoznanie właściwości danego medium w odniesieniu do innych technik, a w konsekwencji zdefiniowanie wyróżniających je właściwości ${ }^{26}$.

Wstęp do instrukcji Wiedźmina konfrontuje grę z innymi mediami poprzez opis, jednak wykładnia tego rodzaju nie musi ograniczać się do środków werbalnych. Już sama obecność paratekstu ustanawia miejsce gry w dyskursie o mediach. Tom, w który zapakowana jest gra Essex, nie służy wyłącznie temu, aby przedstawić fabularne wprowadzenie. Jego fizyczna forma również niesie ze sobą potencjał znaczeń. Opakowanie Essex reprezentuje medium książki i związane z nią metody narracji. Relacja między cyfrowym tekstem gry i książką jako tradycyjną formą narracyjną konstruuje medialną tożsamość obydwu. Dzięki multiplikacji mediów w obrębie jednego tytułu gracz może

25

26 
prześledzić jakościowe i techniczne różnice, które między nimi występują. Jest do tego przez producentów Essex wręcz zachęcany. Na tylnej okładce gry znajduje się bowiem opis, który nakłania do takiej właśnie strategii odbioru, a równocześnie implikuje jej rezultaty i narzuca odbiorcy konkretną interpretację relacji między cyfrową grą i książką: „Każdą elektroniczną powieść rozpoczynasz od przeczytania pierwszych rozdziałów opowieści w tej książce, a potem przechodzisz bezpośrednio do ekranu swojego domowego komputera. Interaktywna przygoda toczy się dalej na dyskietce, wciągając cię we wspaniale sugestywny, pełen akcji świat" ${ }^{\text {"27 }}$. Marketingowemu komentarzowi towarzyszy ilustracja, która przedstawia ekran komputera imitujący otwartą książkę. Jaki zamysł stoi za tak wyraźnym zestawieniem cyfrowego tekstu z medium o odmiennych właściwościach?

$\mathrm{Z}$ jednej strony funkcja medialna paratekstów określa medium gry jako nową jakość, eksponuje te atrybuty, które czynią ją nowym medium. Celem porównania cyfrowego programu ze „starymi” mediami może być np. nazwanie zastosowanych w nim technik narracyjnych innowacyjnymi. Essex odwołuje się do linearnej narracji książkowej po to, aby uwypuklić interaktywość świata gry. Z drugiej strony parateksty mogą także lokować grę w kontekście jej podobieństw do innych mediów. Opisy na opakowaniach i w instrukcjach (np. Ultima VII zostaje nazwana „pierwszym rozdziałem trzeciej księgi nagradzanej sagi Ultima") oraz specyficzne nazewnictwo stosowane przez producentów (np. interaktywna fikcja ${ }^{28}$, interaktywne powieści) sugerują pokrewieństwo gier z tradycyjnymi formami narracyjnymi. Zapakowana w książkę gra rości sobie prawo do bycia kompetentnym utworem fabularnym. Jest nie tyle zaprzeczeniem tradycji literackiej, co jej kontynuacją.

\section{Funkcja ekonomiczna}

Kategoria funkcji medialnej nie wyczerpuje problematyki związanej z technologiczną płaszczyzną gier. Stąd też wskazanie trzeciej podstawowej funkcji paratekstów, funkcji ekonomicznej, która wynika z uwikłania paratekstów w materialne i rynkowe aspekty produkcji gier. Często to właśnie rynkowe

27 Tłumaczenie własne, w oryg: "You start each Electronic Novel by reading the first chapters of the story in this book, and then go directly to the screen of your home computer. The interactive adventure picks up on diskette, pulling you into an excitingly vivid, action-packed world". Synapse Software Essex, Brøderbund 1985, opakowanie.

Termin stosowany przez firmę Infocom. 
i technologiczne warunki dyktują konieczność suplementacji gry o dodatkowe teksty i przedmioty. Prateksty pozostają wówczas pod wpływem zabiegów marketingowych, metod dystrybucji i sprzedaży, technologicznych uwarunkowań platform, na które gry powstają, jak również ograniczeń samego medium gry.

Parateksty mogą więc służyć pozyskaniu dla gry odbiorcy (klienta) i wpływać na jej sprzedaż. Opakowania gier firmy Synapse, które przypominają książki; gadżety dodawane do programów Infocom pomagały w zwiększeniu rozpoznawalności produktu. Marketingowe pojęcie „feelies” utrzymuje się w kręgach fanów gier Infocom do dziś i stanowi wyróżnik programów produkowanych przez tę firmę, mimo że także inni producenci stosowali podobne zabiegi.

Kategoria funkcji ekonomicznej obejmuje również te przypadki, gdy paratekst wypełnia technologiczne niedoskonałości gry, tak jak dzieje się w Suspended firmy Infocom. Program wciela gracza w rolę pogrążonego w kriogenicznym śnie człowieka, którego umysł stanowi rdzeń kompleksu zarządzającego zamieszkałą przez ludzi planetą Contra. Pozbawiona ruchów postać zostaje w wyniku awarii zmuszona pokierować sześcioma robotami i przywrócić ład na stacji. Tekstowa gra wymaga więc od użytkownika dalekosiężnego planowania działań wielu jednostek. Dlatego też Suspended zostało wydane wraz z mapą i żetonami reprezentującymi roboty. Rozgrywka toczy się równocześnie na ekranie monitora i planszy dostarczonej przez wydawcę. Dzięki temu graczowi łatwiej zorientować się w eksplorowanym terenie.

Funkcja ekonomiczna to także parateksty, których powstanie jest konsekwencją właściwości platformy, na którą dana gra została zaprojektowana. Gry publikowane na konsolę Intellivision były wydawane wraz z elastycznymi nakładkami, które po wsunięciu w kontroler przykrywały przyciski służące do obsługi programu. Nakładki do poszczególnych gier różnią się od siebie, zwykle jednak zawierają ilustracje, które kontekstualizują interakcję z kontrolerem (a przez to i z grą). Nakładka do Dragonfire przedstawia uproszczony widok z gry (mężczyzna biegnący przez dziedziniec zamku) wraz ze wskazaniem miejsc na kontrolerze, które należy przycisnąć, aby zmusić postać do skoku lub poruszania się w odpowiednim kierunku.

\section{Arcydzieło grozy}

Ścisłe rozgraniczenie na trzy modele funkcjonalne paratekstów ma charakter poglądowy. Jeden paratekst może odgrywać wiele ról jednocześnie, a żadna 
$\mathrm{z}$ nich nie dominuje nad pozostałymi. Często trudno określić, która z funkcji determinowała powstanie paratekstu. Nawet jeżeli paratekst powstał pod wpływem przesłanek ekonomicznych, jego potencjał narracyjny i medialny niekoniecznie zostanie przez gracza zignorowany. Powróćmy do przykładu, który otworzył nasze rozważania o paratekstualności gier; jest on dobrą ilustracją nawarstwiania funkcji paratekstów. Layers of Fear.Artbook, bo taki tytuł nosi wolumin z grafikami załączony do gry studia Bloober, jest kontaminacją trzech podstawowych funkcji.

Ekonomiczny wymiar książki określa fakt, że jest to przedmiot kolekcjonerski, który zwiększa wartość limitowanej edycji gry. Nie jest on dostępny w wydaniu podstawowym, a przez to uzasadnia wyższy koszt specjalnej wersji produktu. Może zostać również zinterpretowany jako rozszerzenie technologicznych aspektów gry, która umieszcza część przedstawionych w nim obrazów w interaktywnym środowisku 3D. Odbiór prac zanurzonych w diegezie gry będzie nieco inny niż ich kontemplacja na kartach książki. W pierwszym wypadku będą się one pojawiać w kontekście świata przedstawionego gry, w drugim mogą zaistnieć w oderwaniu od niego. Autorzy zaznaczają ten odmienny charakter książki i gry we wstępie, pisząc, że „tę książkę z dumą umieścicie na półce, zaś w samej grze zatopicie się na godziny pełne niezapomnianego szaleństwa i psychodeli"29.

Przechodzimy zatem do funkcji medialnej paratekstu. Symptomatyczne dla gier porównywanie z nieinteraktywnym medium, którego miejsce jest "na półce”, nie wymaga większego komentarza. Artbook nie reprezentuje jednakże tylko formy książki. Zgodnie z tezą McLuhana przenosi również inne media, w tym twórczość plastyczną uobecnioną na jego stronach. Książka przedstawia prace zespołu artystów, których wysiłek poprzedził powstanie programu. Obrazom towarzyszy dodatkowo odautorski komentarz na temat tytanicznej pracy grafików, a także nazewnictwo na opakowaniu, odsyłające do świata sztuki („arcydzieło strachu”,,,edycja konesera”). Książka służy temu, aby nadać grze rangę profesjonalnego produktu artystycznego. Konsekwencją zdemaskowania aktu kreacji jest ujawnienie procesu mediacji. Podczas rozgrywki użytkownik może np. wykorzystać materiał z książki do prześledzenia różnic i podobieństw między malarskim konceptem a jego realizacją w silniku gry.

Co nie oznacza, że omawiany paratekst nie realizuje funkcji narracyjnej. Ilustracje zamieszczone w książce są wszakże przedłużeniem procesu 
reprezentacji, który odbywa się w grze; ewokują świat Layers of Fear. Towarzyszą im wycinki z gazet, listy i notatki postaci z gry, które jeszcze bardziej intensyfikują funkcję narracyjną paratekstu. Zbiór różnorodnych artefaktów ukazuje świat gry z innej perspektywy, za pomocą innych technik medialnych. W związku z powyższym paratekst może inicjować powrót w obręb narracji bądź wzmacniać immersję użytkownika. W końcu, wpleciony między obrazy cytat z Portretu Doriana Graya, rzuca nowe światło na fabułę, każe doszukiwać się w grze literackich inspiracji.

\section{Parateksty a interfejs}

Przykład książki załączonej do Layers of Fear ukazuje splot różnorodnych funkcji paratekstualnych, które kształtują recepcję gry. Przegląd wpływających na siebie funkcji uwydatnia to, że znajdują się one zarówno „wewnątrz", jak i na „zewnątrz. Relacja między grą i jej paratekstami zachodzi na poziomie diegetycznym i pozadiegetycznym. Te cechy łączą parateksty z ideą interfejsu.

Strukturalne i funkcjonalne podobieństwa interfejsu oraz paratekstu dostrzegł Alexander R. Galloway, który w książce The Interface Effect dokonuje przeglądu teorii opisujących tytułowy fenomen. Galloway próbuje rozwinąć popularne w nauce metafory interfejsu jako drzwi lub okien (a więc metafory zbliżone do tych, które artykułują koncept paratekstu). Badacz zauważa, że wskazane przenośnie wynikają ze spopularyzowanego przez Marshala McLuhana rozumienia mediów jako „naczyń”, które zawierają w sobie i przekształcają inne media ${ }^{30}$. Jeśli medium jest kontaminacją innych mediów to interfejs musi być elementem umożliwiającym przechodzenie między różnymi warstwami medialnych poetyk. Musi on być miejscem „liminalnym”, które znajduje się na styku różnych form, a jednocześnie pozwala tym formom zaistnieć w obrębie większej całości. Interfejs jest więc rodzajem ramy, która aby umożliwić interakcję z danym medium, oddziela centrum od jego krańców - medium od aktu mediacji ${ }^{31}$.

Analogia między koncepcjami interfejsu i paratekstu jest na tyle duża, że można pokusić się o ich zamienne używanie, co też zresztą Galloway czyni. Jednak w jego pracy zwraca uwagę wskazanie ograniczeń związanych z rozpowszechnioną konceptualizacją interfejsu (a co za tym idzie paratekstu).

Zob. M. McLuhan Understanding Media. The Extensions ofMan, The MIT Press, Cambridge-London 1994, s. 8. 
Metafora okien zakłada, że rama nie oddziałuje na informację, którą ma przekazywać; metafora drzwi natomiast porusza się między dwoma skrajnościami: otwarcia bądź zablokowania przekazu. Oznaczałoby to, że możliwe jest jedynie albo doświadczanie danego medium, tak jakby interfejs (paratekst) w ogóle nie istniał, albo ujawnienie interfejsu (aktu mediacji), a przez to zniweczenie przekazu ${ }^{32}$.

Przeprowadzona w niniejszym artykule analiza działania paratekstów wykazuje, że tak nie jest. To, co wydaje się „obok”, może znacząco modyfikować znaczenie tekstu. Co więcej, w pewnych wypadkach rozgraniczenie na główny tekst i jego uzupełnienia jest niemożliwe. Czy zatem u podłoża teorii Genette'a leży błędne rozróżnienie na tekst główny i tekst poboczny? Wręcz przeciwnie, to właśnie koncepcja paratekstu pozwala dostrzec, że te dwie z pozoru oddzielne kategorie tekstów tworzą immanentną całość. Paratekstualność jest przecież, jak określił to Genette, przestrzenią nierozstrzygalności między „wnętrzem” a tym, co je otacza. Nierozstrzygalności, ponieważ to pogranicze tekstu dyktuje recepcję całości33. Paratekstualność nie jest zatem mechanizmem, którego celem jest wytworzenie hierarchicznej zależności między grami i ich dodatkami. Zmierza on bowiem ku symbiozie, w której odmienne produkty medialne współtworzą procesy odbioru. Galloway wykorzystuje ten tok rozumowania, aby stwierdzić, że nie powinniśmy myśleć o interfejsach i paratekstach jako o oddzielnych obiektach, a raczej jako o strumieniach nakładających się na siebie efektów. Tworzą one zbiór działających równocześnie „wydarzen”" („parallel events”), czyli procesów recepcji danego tworu oraz narosłego wokół społecznego dyskursu ${ }^{34}$.

Na podstawie argumentów Gallowaya można wysnuć wniosek, że parateksty nie zapośredniczają tekstu gry, ale go transformują. Paratekstualność to mechanizm, który nie tyle przekazuje, co konfiguruje narrację i medialność gry; jest procesem, w którym różne funkcje wchodzą w zależności, wzbogacając i jednocześnie komplikując odbiór gry. Użytkownik nie doświadcza gry jako ściśle określonego tekstu i medium, lecz w toku paratekstualnych procesów ciągle go rewiduje. Różnorodne interakcje gracza z paratekstami (bądź też ich brak) mogą prowadzić do odmiennej interpretacji zarówno świata wykreowanego przez narrację, jak i cech medialnych danej gry. Nie wszystkie

\footnotetext{
32 Tamże, s. 40-41. 
funkcje muszą zostać przez użytkownika „aktywowane", może się to też stać na różnych etapach doświadczania gry.

Paratekst zawiera w sobie potencjał różnorodnych układów, które odbiorca przemierza według własnego uznania. Jest przestrzenią, do której wciąż się powraca. Teoria paratekstu jest więc narzędziem, które pozwala przyjrzeć się systemowi połączonych z grą tekstów, a także potencjalnym strategiom odbioru, będących ich efektem. Pokrewieństwo paratekstów i interfejsów podpowiada, że teoria Genette'a nadaje się do rozważań na temat tekstów wplecionych w cyfrową tkankę gry. Zbadanie funkcjonalności intra- i pozadiegetycznych interfejsów przypuszczalnie pozwoli na przejście od synchronicznego oglądu do analizy diachronicznej. Kolejnym krokiem w badaniach nad paratekstami powinno być przyjrzenie się ich ewolucji w kulturze gier oraz materialnym i ekonomicznym zmianom, które je dotknęły. Metoda paratekstualna może być również przydatna w rozważaniach na temat relacji, które powstają między produktami w obrębie dużych marek popkulturowych lub adaptacji. Przykładowo, czy książka z opowiadaniami Andrzeja Sapkowskiego dołączona do gry Wiedźmin powinna być traktowana jako próba stworzenia jednolitego, transmedialnego uniwersum, czy może jako autonomiczny, niezwiązany z grą tekst (opowiadania powstały przecież na długo przed jej wydaniem)? Perspektywa paratekstualna sugeruje, że dochodzi w takim przypadku do pochłonięcia pierwowzoru. Traci on swój niezależny status, co (być może) prowadzi do ukrycia faktu, że to gra powstała na jego podstawie. Warto więc wykorzystać paratekstualność jako pretekst do zastanowienia się nad problematycznym statusem transmedialności. Wszystkie te wstępnie zarysowane wątki badawcze wciąż czekają na eksplorację. 


\section{Abstract}

\section{Michał Żmuda}

RZESZÓW UNIVERSITY

Paratexts of Video Games: Game Reception and Paratextual Functions and Processes

Rzeszowski explores the printed paratexts of video games. Drawing on Gérard Genette's theory of transtextuality, he points out that paratexts are related to authors' attempts to control the texts' reception. Three functions of paratexts in games are highlighted, namely the narrative function, the medium-based function, and the commercial function. Paratexts give depth to the narrative and the gameworld. They define the game's mediality, confronting it with texts that have different properties. They are bound up with the material and market-based aspects of production. These functions give rise to a network of mutual interdependencies that impact a game's reception. Rzeszowski defines paratextuality as a process that not only mediates the narrative and mediality of a game but also configures it.

\section{Keywords}

video games, paratextuality, interface, narrative 